Tilletia walkeri, a New Species on Lolium multiflorum and L. perenne Author(s): L. A. Castlebury and L. M. Carris

Source: Mycologia, Vol. 91, No. 1 (Jan. - Feb., 1999), pp. 121-131

Published by: Mycological Society of America

Stable URL: http://www.jstor.org/stable/3761200

Accessed: 19-10-2015 22:43 UTC

\title{
REFERENCES
}

Linked references are available on JSTOR for this article:

http://www.jstor.org/stable/3761200?seq=1\&cid=pdf-reference\#references_tab_contents

You may need to log in to JSTOR to access the linked references.

Your use of the JSTOR archive indicates your acceptance of the Terms \& Conditions of Use, available at http://www.jstor.org/page/ info/about/policies/terms.jsp

JSTOR is a not-for-profit service that helps scholars, researchers, and students discover, use, and build upon a wide range of content in a trusted digital archive. We use information technology and tools to increase productivity and facilitate new forms of scholarship. For more information about JSTOR, please contact support@jstor.org. 


\section{Tilletia walkeri, a new species on Lolium multiflorum and L. perenne}

\author{
L. A. Castlebury ${ }^{1}$ \\ USDA-ARS Systematic Botany and Mycology Lab, \\ 10300 Baltimore Avenue, Beltsville, MD 20705-2350 \\ L. M. Carris \\ Department of Plant Pathology, Washington State \\ University, Pullman, WA 99164-6430
}

\begin{abstract}
Tilletia walkeri (Ustilaginales: Tilletiaceae) is described as a new species of partial bunt infecting Lolium multiflorum, annual ryegrass, and L. perenne, perennial ryegrass in the United States and Australia, respectively. The new species is characterized by large, tuberculate teliospores with the exospore ornamentation comprised of incompletely cerebriform ridges in surface view. Teliospores of $T$. walkeri are compared with those of T. indica and other similar species of Tilletia, and the issue of Neovossia versus Tilletia is discussed. A key is provided to smuts known to occur on species of Lolium.
\end{abstract}

Key Words: Karnal bunt, ryegrass, smut fungi, Tilletiaceae, Ustilaginales

\section{INTRODUCTION}

The first report of Tilletia indica Mitra, the Karnal bunt (KB) fungus, in Arizona durum wheat (Triticum durum Desf.) seed in March 1996 (Ykema et al 1996) initiated a national survey program to determine the extent of the disease in the USA. The presence of KB had serious implications for the $\$ 5$ billion USA wheat export industry, as many countries importing wheat in 1996, including the USA, would not accept wheat from any country known to have $T$. indica. Teliospores of T. horrida Tak., the rice kernel smut fungus, are morphologically similar to those of $T$. indica, and the disease is widespread in the southern rice-growing regions of the USA (Whitney 1989). At the time T. indica was discovered in Arizona, a polymerase chain reaction (PCR)-based test was available to distinguish viable $T$. indica teliospores from $T$. horrida [as T. barclayana (Bref.) Sacc. and Syd. in Sacc.; Smith et al 1996].

During the national KB survey, T. indica-like telio-

Accepted for publication July 17, 1998.

${ }^{1}$ Email: lisa@nt.ars-grin.gov spores were found in wheat seed washes from the southeastern USA, and from seed washes of pasture mixes containing wheat and ryegrass (Lolium spp.) from Oregon. The teliospores were on average smaller, paler in color, and had coarser ornamentation on the exospore than those of $T$. indica. The teliospores tested positive for T. indica using the PCR test (Bonde et al 1997), although bunted wheat seeds were not found in the southeastern USA or Oregon despite extensive searches. The source of the T. indica-like teliospores was unknown until Jan 1997 when bunted seeds of annual ryegrass ( $L$. multiflorum $\mathrm{L}$.) were recovered from commercial seedlots produced in Oregon's Willamette Valley (Bonde et al 1997). Bunted seeds were later found in annual ryegrass growing as weeds in wheat fields in the southeastern USA (Bonde et al 1997). In Feb 1997, one of us (LMC) found four specimen packets from Herb. DAR of a Tilletia species on Lolium perenne L., identified by Mr. John Walker from seed grown in 1967 and 1968 in Australia's Kangaroo Valley. The specimens were among the smut collection left by Prof. Rubben Durban after his retirement from the Department of Plant Pathology at Washington State University. The specimens had been sent to Durban for identification, and he had noted on one packet that the fungus appeared to be a new species, but the material in the specimens was inadequate to make a determination. The herbarium packets were later determined to be part of 22 specimens of the $L$. perenne smut deposited as Tilletia sp. at the Agricultural Research and Veterinary Centre, Orange, New South Wales, Australia. According to Michael Priest, curator of Herb. DAR (pers comm), 21 of the specimens in DAR are from the Kangaroo Valley, collected between 1967 and 1974, and each packet contains one or two bunted seeds. One collection of the $L$. perenne smut is a prepared slide of teliospores forwarded to Walker from New Zealand in 1976, but the precise date and location of the specimen is not known. Walker had noted on Australian specimen DAR 16719, collected Dec 28, 1967, that this was the first record of a Tilletia sp. on Lolium in New South Wales. The teliospores from Australian bunted perennial ryegrass seeds were similar to those recovered in the seed washes and bunted annual ryegrass seeds in the USA.

The DAR specimens demonstrate that this smut has been present on ryegrass for at least $30 \mathrm{yr}$. Sub- 
sequent surveys of commercial ryegrass from the Willamette Valley showed that the teliospores were present in at least $60 \%$ of the seedlots tested (Bonde et al 1997), and could be found in seedlots going back to 1989 (G. Milbraith, Oregon Department of Agriculture pers comm). The smut was also found in 1997 in annual ryegrass growing along a roadside ditch southwest of Portland in Yamhill County, Oregon (Carris unpubl). Molecular characterization of the ryegrass smut using RAPD, RFLP-ITS and ITS sequence analyses showed that it is distinct from $T$. indica, although it is more similar to this species than to the other tuberculate-spored Tilletia species tested, including T. horrida (Pimentel et al 1998; L. Levy, USDA-APHIS pers comm). The widespread nature of the ryegrass bunt, its relatively long association with ryegrass, and its morphological and molecular distinctions from T. indica provide support for describing it as a new species of Tilletia.

\section{MATERIALS AND METHODS}

Collections examined are listed in TABLE I. Teliospores were mounted in Shear's solution [ $50 \mathrm{~mL} 2 \%(\mathrm{w} / \mathrm{v})$ potassium acetate, $20 \mathrm{~mL}$ glycerol, $30 \mathrm{~mL} 95 \%$ ethyl alcohol], warmed overnight at $45 \mathrm{C}$ to evaporate excess mounting medium, and examined under bright field (BF) or differential interference contrast $(\mathrm{DIC})$ microscopy at $\times 1000$. Monochrome teliospore images were captured via a video camera mounted on the microscope and connected to a personal computer. Average diam (average of the longest and shortest lines through the center of the spore that join two points on the perimeter) of the total spore (including ornamentations) were automatically measured with ImagePro Plus 3.0 image analysis software (Media Cybernetics, Silver Spring, Maryland). Teliospore shape, color, and exospore ornamentation were also recorded. Thirty spores from each collection were examined. For scanning electron microscopy (SEM), dry teliospores were mounted on double-sided tape, coated with gold, and examined at $\times 1500, \times 2000$, and $\times 3500$ with a JEOL JSM-T300 scanning electron microscope.

Ryegrass seeds were soaked 1-2 d in tap water to render the palea and lemma transparent, and examined at $\times 20$ for discrete darkened areas indicative of partial bunt. For germination, teliospores were soaked an additional $2 \mathrm{~d}$ in distilled water, surface-sterilized in $0.26 \% \mathrm{NaClO}(5 \% \mathrm{com}$ mercial bleach) in a 1.5-mL Eppendorf tube for $50 \mathrm{~s}$, pelleted by centrifugation at approximately $13000 \mathrm{~g}$ in a benchtop microcentrifuge for $10 \mathrm{~s}$, and rinsed once with sterile distilled water. Surface-sterilized teliospores were streaked on $2 \%$ water agar (WA) and incubated at room temperature (20-25 C). Primary sporidia from 10 teliospores per collection were counted, and 20 primary sporidia per teliospore were measured. Sporidia and mycelium of the ryegrass smut were fixed and stained with Giemsa-HCl following Durban (1980).

\section{RESULTS}

The highest level of infection among the Lolium seedlots examined in this study was TN $97-770$, in which there were eight bunted seeds found in $40 \mathrm{~g}$ of seed (bunted seeds deposited as WSP 69698). Teliospores of the ryegrass smut started germinating in 2-5 $\mathrm{d}$ on WA at room temperature. Germination occurred by the formation of a promycelium with a terminal whorl of primary sporidia (FIGS. 2, 3). Primary sporidia germinated within $24 \mathrm{~h}$ by the formation of forcibly discharged allantoid secondary sporidia. The secondary sporidia germinated to produce secondary sporidia or mycelium and filiform secondary sporidia were also produced from the mycelium (FIGS. 4-10). No fusion was observed between primary or secondary sporidia on agar.

\section{TAXONOMY}

Tilletia walkeri L. A. Castlebury et L. M. Carris, sp. nov. FIGS. 1-16, 29-31

Sori in uno vel duobus ovariis per spicas, inconspicui; massa sporarum fusca; steriles cellulae globosae, subglobosae vel lacrimiformes, hyalinae vel pallidae fulvaeo, 13-26 $\mu \mathrm{m}$ diametro, cum crassis parietibus 3-5 $\mu \mathrm{m}$; sporae globosae vel subglobosae, flavidae vel atro-badiae vel opacae, 23.7-44.4 $\mu \mathrm{m}$ diametro; episporium cum conicae vel acutae eminentiae 3-6 $\mu \mathrm{m}$ longae sunt.

Sori in the ovaries enclosed by the pericarp, inconspicuous, infecting only one or two per spike, ovaries usually only partially destroyed; infection mostly restricted to the palea side of the seed; spore mass dark brown; with no discernible odor. Sterile cells globose, subglobose to lacrimiform, hyaline to dark yellow-brown, 13-26 $\mu \mathrm{m}$ diam; walls smooth, laminated, 3-5 $\mu \mathrm{m}$ thick (FIG. 1). Teliospores globose to subglobose, pale yellow to dark reddish-brown, opaque to subopaque, 23.7-44.4 $\mu \mathrm{m}$ diam ( $5 x=$ $34.0 \mu \mathrm{m})$; exospore ornamented with conical to truncate projections 3-6 $\mu \mathrm{m}$ high which from surface view appear coarsely and incompletely cerebriform to coralloid; with hyaline to yellowish brown sheath extending to tips of projections (FIGS. 11-16, 29-31). Promycelium multinucleate. Primary sporidia (36-)60-150(-230) per promycelium, formed in a terminal whorl, hyaline, filiform, curved, 38-75 $\times$ $1.3-1.8 \mu \mathrm{m}$ (range of mean lengths and widths from a single teliospore $=44.3-67.8 \times 1.3-1.7 \mu \mathrm{m}$ ); sporidia initially mononucleate, quickly undergoing nuclear divisions and forming inconspicuous septa between daughter nuclei, typically one septum per sporidium; fusions between sporidia lacking (FIGS. $2,3)$. Secondary sporidia of two types: allantoid and filiform; allantoid type with truncate base, hyaline, 10.6-17.6 $\times 1.8-3.1 \mu \mathrm{m}$; filiform type, curved, hya- 
TABLE I. Tilletia collections examined

\begin{tabular}{|c|c|c|c|}
\hline Specimen & Location & Host & Date collected \\
\hline \multicolumn{4}{|l|}{ T. eragrostidis } \\
\hline WSP 60857 & Australia (QLD) & Eragrostis japonica & 8 Jul 1954 \\
\hline WSP 63954 & USA (MS) & E. glomerata & 10 Sep 1904 \\
\hline WSP 34668 & USA (MS) & E. glomerata & 8 Sep 1904 \\
\hline BPI 172896 & USA (MS) & E. glomerata & 8 Sep 1904 \\
\hline \multicolumn{4}{|l|}{ T. horrida } \\
\hline BPI 173389 & Burma & Oryza sativa & 29 Nov 1912 \\
\hline BPI 173388 & China & O. sativa & 15 Sep 1926 \\
\hline BPI 174228 & India (Punjab) & O. sativa & 17 Oct 1954 \\
\hline BPI 174224 & Senegal & $O . \mathrm{sp}$. & 20 Dec 1967 \\
\hline BPI 174227 & Pakistan & O. sativa & Nov 1952 \\
\hline BPI 174229 & Philippine Islands & O. sativa & 31 Mar 1964 \\
\hline BPI 802756 & USA (AR) & O. sativa & 27 Jun 1993 \\
\hline BPI 173394 & USA (TX) & O. sativa & 1936 \\
\hline BPI 174226 & USA (TX) & O. sativa & 1940 \\
\hline \multicolumn{4}{|l|}{ T. indica } \\
\hline BPI 174231 & India & Triticum sp. & 5 Apr 1948 \\
\hline BPI 174230 & India & Triticum sp. & Dec 1942 \\
\hline BPI 174233 & India (Karnal) & T. aestivum & Apr 1954 \\
\hline BPI 195164 & India (Karnal) & T. vulgare & Mar 1937 \\
\hline BPI 174235 & India & T. vulgare & 23 Dec 1943 \\
\hline BPI 174236 & India & T. vulgare & 20 Apr 1942 \\
\hline BPI 174232 & India & Triticum sp. & 10 Aug 1948 \\
\hline BPI 174234 & Afghanistan & T. aestivum & 31 Jan 1955 \\
\hline BPI 749197 & USA (AZ) & T. durum & 4 Mar 1996 \\
\hline BPI 032241 & Mexico & T. aestivum & 8 Jul 1981 \\
\hline BPI 032255 & Mexico & T. aestivum & Mar 1982 \\
\hline BPI 196268 & Mexico & T. aestivum & 24 Jul 1985 \\
\hline BPI 032227 & Mexico & T. aestivum & 19 Apr 1982 \\
\hline BPI 196271 & Mexico & T. aestivum & 13 May 1985 \\
\hline BPI 749272 & Mexico & T. aestivum & 29 Jun 1986 \\
\hline \multicolumn{4}{|l|}{ T. inolens } \\
\hline BPI 195159 & Australia (Victoria) & Deyeuxia forsteri & Nov 1894 \\
\hline \multicolumn{4}{|l|}{ Tilletia sp. } \\
\hline DAR 16719 & Australia (NSW) & Lolium perenne & 28 Dec 1967 \\
\hline DAR 16722 & Australia (NSW) & L. perenne & 24 Jan 1968 \\
\hline DAR 16745 & Australia (NSW) & L. perenne & 16 Feb 1968 \\
\hline DAR 16774 & Australia (NSW) & L. perenne & 2 Mar 1968 \\
\hline BPI 744421 & USA (OR) & L. multiflorum & 1996 \\
\hline WSP 69699 & USA (OR) & L. multiflorum & 1996 \\
\hline WSP 69698 & USA (TN) & Lolium sp. & 1997 \\
\hline WSP 69697 & USA (TN) & Lolium sp. & 1997 \\
\hline BPI 744575 & USA (TN) & Lolium sp. & Feb 1997 \\
\hline
\end{tabular}

line, 26-57.2 $\times 1.8-2.6 \mu \mathrm{m}$; allantoid sporidia forcibly discharged, produced asymmetrically from sporogenous cells formed on hyphae, primary or secondary sporidia; sporogenous cells hyaline, subulate, 4.5-7.0 $\mu \mathrm{m}$ high, 1.3-2.2 $\mu \mathrm{m}$ wide at base, $0.9 \mu \mathrm{m}$ wide at apex (Figs. 4-10).

Etymology. Honoring Mr. John Walker, an eminent Australian mycologist.
HOLOTYPE. USA. OREGON: Benton County, on Lolium multiflorum seeds, 1997, L.M. Carris (BPI 744421). ISOTYPE (WSP 69700).

Additional specimens examined. AUSTRALIA. NEW SOUTH WALES: Kangaroo Valley, Lolium perenne, 11 Mar 1968, det. J. Walker (DAR 16774); Kangaroo Valley, Lolium perenne, 16 Feb 1968, det. J. Walker (DAR 16745); Kangaroo Valley, Lolium perenne, 28 Dec 1967, det. J. Walker (DAR 16722); Kangaroo Valley, Lolium perenne, 24 Jan 1968, det. 


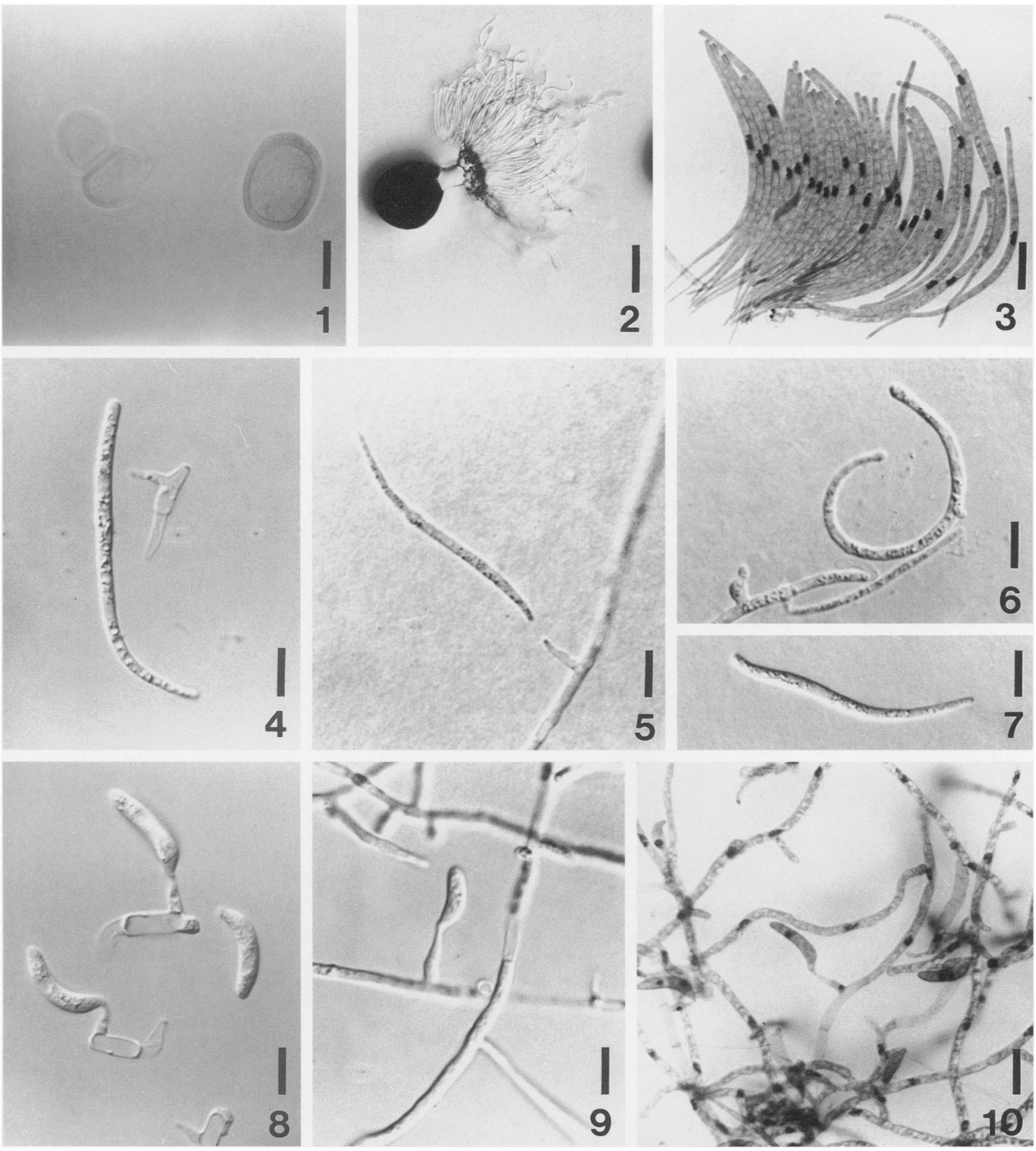

FIGs. 1-10. Tilletia walkeri. 1. Sterile cells. 2. Germinated teliospore with primary sporidia (BF). 3. Giemsa-HCl stain of primary sporidia (BF). 4-7. Filiform secondary sporidia [DIC $(4,6,7)$ and BF Giemsa-HCl stain $(5)] .8,9$. Allantoid secondary sporidia (DIC). 10. Giemsa-HCl stain of allantoid secondary sporidia (BF). Scale bars: $1=12 \mu \mathrm{m} ; 2=20 \mu \mathrm{m} ; 3=8 \mu \mathrm{m}$; 4-10 $=6.7 \mu \mathrm{m}$.

J. Walker (DAR 16719). USA. OREGON: Lane County, 1996 (Tetraploid seedlot WSP 69699); Yamhill County, 2 Jul 1997, coll. \& det. L. M. Carris; TENNESSEE: Lolium sp., Feb 1997, coll. G. L. Peterson, det. L. A. Castlebury (BPI 744575); 97770 (WSP 69698); 97-774 (WSP 69697).

\section{DISCUSSION}

Tilletia walkeri is similar to $T$. indica and $T$. horrida in causing a partial bunt of the host, the large number of nonfusing primary sporidia, and overlapping 


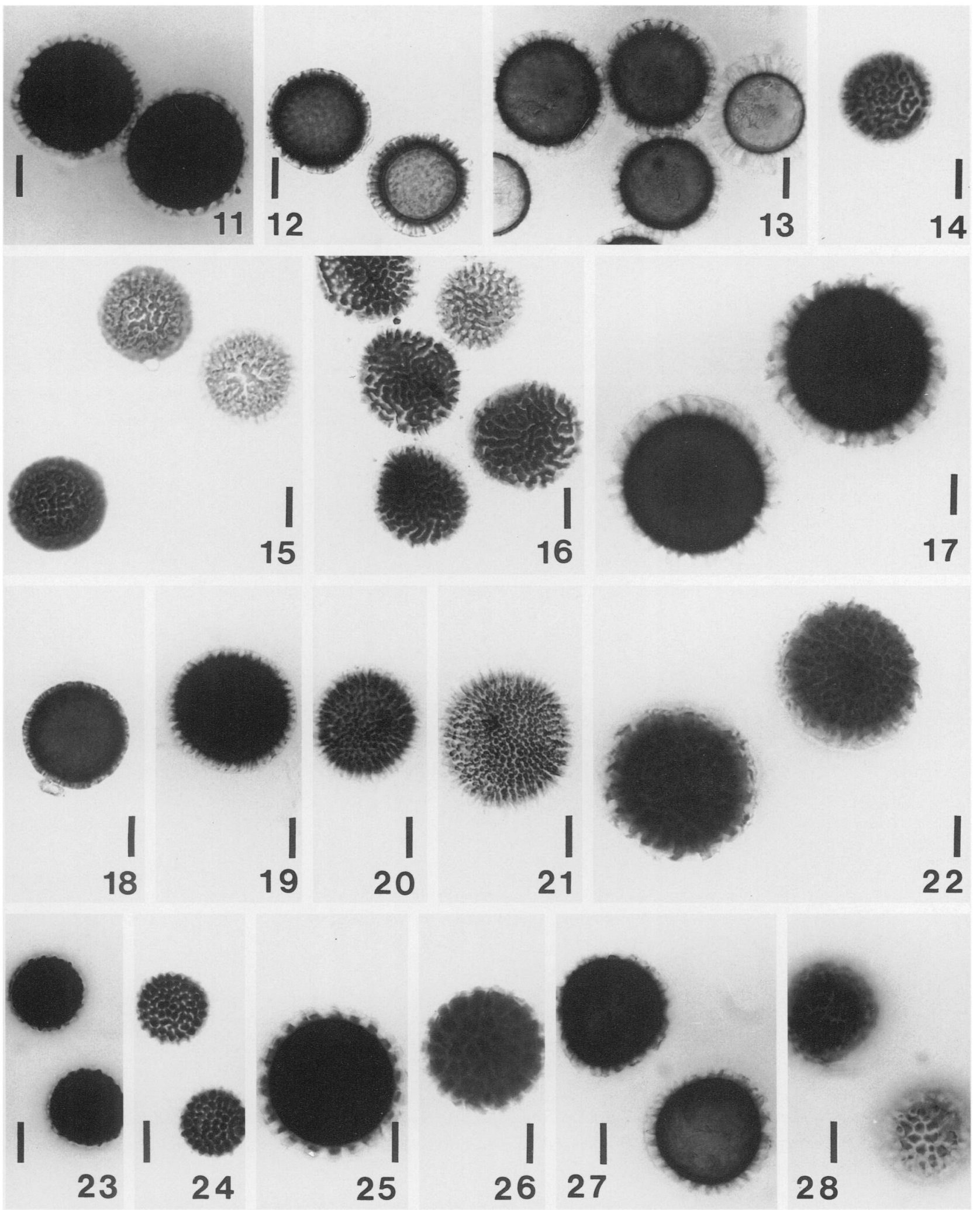

FIGs. 11-28. Teliospores (BF). 11-16. Tilletia walkeri. 17-22. Tilletia indica. 23, 24. Tilletia horrida. 25, 26. Tilletia eragrostidis. 27, 28. Tilletia inolens. Scale bars: $12 \mu \mathrm{m}$. 

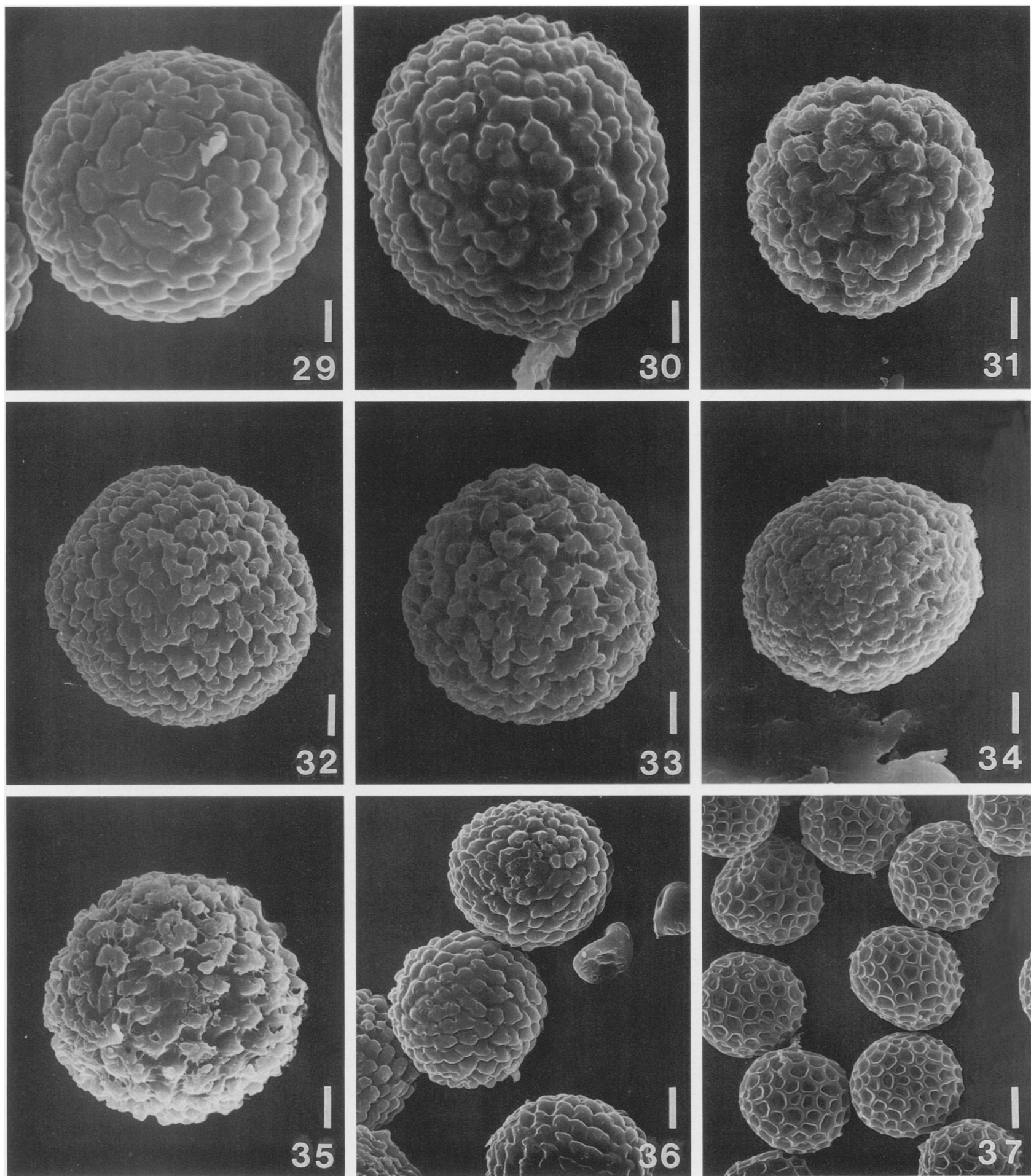

FIGs. 29-37. Teliospores (SEM). 29-31. Tilletia walkeri. 32-34. Tilletia indica. 35. Tilletia eragrostidis. 36. Tilletia horrida. 37. Tilletia lolii. Scale bars: $29,30=3 \mu \mathrm{m} ; 31-37=5 \mu \mathrm{m}$.

teliospore morphology. The teliospores of $T$. walkeri are distinguished from $T$. indica and similar Tilletia spp. by their coarser ornamentation, which in surface view gives the appearance of wide, incompletely cerebriform ridges or thick clumps (FIGS. 14-16, 29-31).
Teliospore color in T. walkeri ranges from pale yellow to dark reddish brown, with a hyaline to yellowish brown sheath enveloping the exospore and range in size from 23.7-44.4 $\mu \mathrm{m}(b x=34.0 \mu \mathrm{m}$, FIG. 38). Teliospores of $T$. indica are more variable in size, color, 


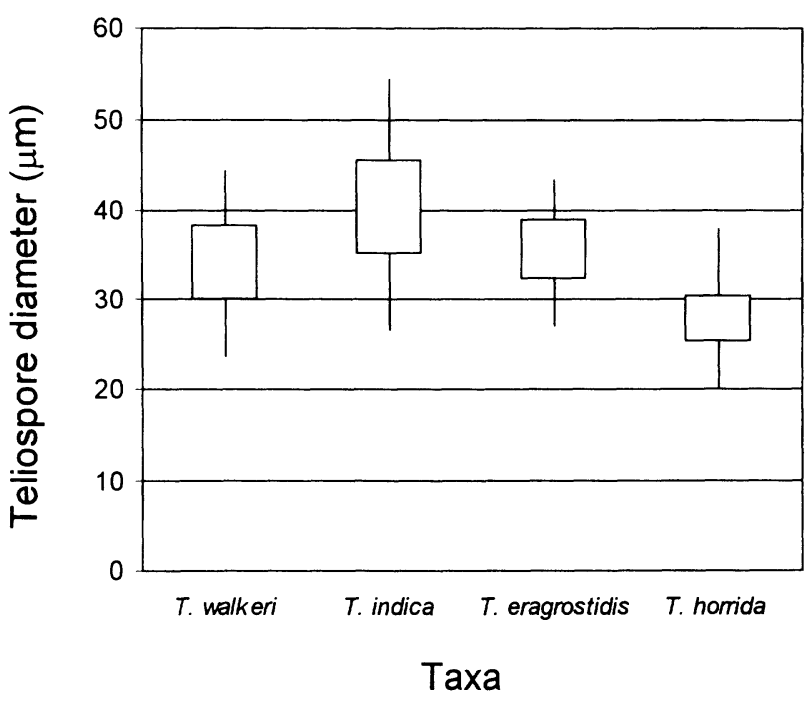

FIG. 38. Mean teliospore diameters. The box indicates the mean $\pm \mathrm{SD}$ and the lines above and below each box indicate the range of measurements.

and ornamentation, ranging in size from 26.6-54.5(63.8) $\mu \mathrm{m}(5 x=40.2 \mu \mathrm{m})$ among the collections examined (FIG. 38). These measurements are slightly larger than those reported by Durban and Fischer (1961) and Durban (1987). One factor that might explain this slight discrepancy is that the teliospores in this study were measured after warming at $45 \mathrm{C}$ overnight. These teliospores tend to swell once placed in the mounting medium and it is not clear how long teliospores were in the mounting medium before measurement in previous studies.

Teliospores of $T$. indica are densely ornamented, with sharply pointed to truncate spines which in surface view appear as either individual spines (densely echinulate), or as closely spaced, narrow ridges (finely cerebriform) (FIGS. 17-22, 32-34). The teliospores may have an apiculus or a short mycelial fragment, more common on immature spores but occasionally present on mature teliospores. The apiculus is a remnant of the sporogenous hypha from which the spore was produced. Spore color in T. indica ranges from pale orange to dark opaque reddish brown with a bright yellow to yellowish brown halo. Most collections of $T$. indica also contain some teliospores that are nearly black and opaque. This feature was not found in field collections of T. walkeri. Khanna and Payak (1968) reported that the exospore ornamentations of T. indica were truncate with flattened to occasionally curved tips, which at times became torn or forked. This type of ornamentation has also been observed in T. walkeri. Because the characters of color and size of the teliospores intergrade between these two species, these cannot be considered reliable characters for distinguishing these fungi based on the examination of only a few teliospores. Additionally, when the teliospores are examined with SEM, the sheath present on the teliospores may partially mask the exospore preventing a reliable comparison of the exospore of the two species. Matsumoto and Bell (1989) used a chemical treatment to remove the sheath on teliospores of T. horrida (as Neovossia barclayana) and showed SEM comparing the teliospores with and without the sheath. The exospore on the teliospore with the intact sheath was bluntly echinulate (similar to the illustrations in this paper), whereas the teliospore without the sheath was densely echinulate with sharply pointed spines. Unfortunately the authors did not describe the method they used to remove the exospore. The scanning electron micrographs of Durban (1987) and Vbanky (1994) illustrate Tilletia teliospores with intact sheaths.

A direct comparison of teliospore germination in T. indica and T. walkeri was not possible because of the limitations in working with living material of $T$. indica due to its quarantined status. However, based on published reports there appear to be several differences in germination between the two species. In a study examining the physical and chemical factors affecting teliospore germination in T. indica, Krishna and Singh (1982a) reported that the maximum germination occurred at 20-25 C in teliospores soaked $7 \mathrm{~d}$ in tap water. Teliospores of T. indica germinate in 5-7 d under optimal conditions (Durban 1972, Holton 1949, Smilanick et al 1985). Teliospores of $T$. walkeri began germinating in 2-3 $\mathrm{d}$ in the Tennessee collections, and in $5 \mathrm{~d}$ in the Oregon collections. Teliospores of $T$. indica germinate to produce 26-171 primary sporidia (Holton 1949), similar to T. walkeri. Peterson et al (1984) reported the range of the mean length and width of the primary sporidia in $T$. indica as 64.4-78.8 $\times 1.6-1.8 \mu \mathrm{m}$ based on a comparison of four collections from India and three collections from Mexico. The authors noted that there were no significant differences for these parameters among the collections examined. If these dimensions are representative of the species, then the primary sporidia of $T$. indica, on average, are somewhat longer than those of $T$. walkeri. The significance of differences in primary sporidia is difficult to assess because there are no studies directly comparing the size of primary sporidia between closely related species. A more comprehensive comparison of primary and secondary sporidia in T. indica, T. walkeri, and other species of Tilletia is needed to demonstrate whether sporidial morphology is a reliable character in the taxonomy of this group.

Prior to the discovery of $T$. walkeri, T. horrida was considered the species most likely to be mistaken for 
T. indica in the national $\mathrm{KB}$ survey. Teliospores of Tilletia horrida (FIGS. 23, 24, 36) range from 20.3$37.9(-41.4) \mu \mathrm{m}(\boldsymbol{b} \boldsymbol{x}=27.8 \mu \mathrm{m})$ in total spore maximum diam with curved sharply pointed to truncate spines that in surface view appear as polygonal scales. The teliospores of $T$. horrida are distinctly smaller than those of T. indica and T. walkeri (FIG. 38). Other species of Tilletia with tuberculate teliospores in the size range of $T$. indica and T. walkeri include T. inolens McAlp. on Deyeuxia forsteri Kunth. from Australia and T. eragrostidis Clint. \& Ricker on Eragrostis glomerata (Walter) L. Dewey from the southern USA (Durban and Fischer 1961). Walker had indicated on DAR 16719 that the ryegrass smut was most similar to $T$. inolens. Only a few teliospores of $T$. inolens (FIGS. 25, 26) were available for study (TABLE I) and no viable collections of $T$. inolens and $T$. eragrostidis were available for any of the molecular studies cited. However, Durban and Fischer (1961) state that the spores of T. inolens are 31-41 $\mu \mathrm{m}$ diam with coarse warts. Teliospores of T. eragrostidis (FIGs. 27, 28, 35) range from $27.0-43.3 \mu \mathrm{m}$ diam $(b x=35.6) \mu \mathrm{m}$ (FIG. 38 ). In surface view, the exospore ornamentation of both species appears much more coarse and blunt than that of T. walkeri. In addition, these two species apparently do not have the cerebriform appearance that teliospores of $T$. walkeri typically exhibit.

In an experimental host range study utilizing a boot injection inoculation technique, Royer and Rytter (1988) showed that $T$. indica was able to infect 20 species of grasses in Aegilops, Bromus, Lolium, Oryzopsis and Triticum. However, T. indica is only known to infect Triticum species and triticale $(\times$ Triticosecale) under natural conditions (Fuentes-Davila 1996). Other smuts known to infect Lolium include Ustilago hypodytes (Schlechtend.) Fr., U. bullata Berk., U. lolii P. Magnus, U. striiformis (Westend.) Niessl, Urocystis bolivari Bub. \& Gonz. Frag., and Entyloma dactylidis (Pass.) Cif. (Figs. 39-45, 48, 49) (Farr et al 1989, Vbanky 1994, Zundel 1953). The only species of Tilletia reported to infect Lolium spp. are T. controversa Kbuhn, T. laevis Kbuhn, T. lolii Auersw. and T. tritici (Bjerk.) Wint. (Farr et al 1989, Vbanky 1994). Vbanky (1994) lists T. laevis Kbuhn as an experimental host (artificially inoculated). Tilletia lolii, T. tritici, and T. controversa (FIGS. 46, 47, 50-53) have reticulate teliospores, while the spores of $T$. laevis are smooth. Zundel (1953) also lists Lolium spp. as hosts for Ur. agropyri (G. Preuss) J. Schrbot. (Hungary) and Ur. occulta (Wallr.) Rabenh. ex Fuckel (Hungary and Australia). Two specimens identified as Ur. occulta on Lolium perenne in the U. S. National Fungus Collection (BPI) could not be distinguished from Ur. bolivari. Neither Vbanky (1994) nor Lindeberg (1959) list Lolium as a host for Ur. agropyri or Ur. occulta and Vbanky (1994) lists Lolium as a questionable host for U. tritici (Pers.) Rostr. Due to the uncertainty of the identifications of hosts and fungi in these cases, Ur. agropyri, Ur. occul$t a$, and $U$. tritici will not be discussed further.

Two other fungi with spores superficially resembling smut teliospores were frequently found in the seed washes from the national KB survey. Conidia of Epicoccum purpurascens Ehrenb. (FIGS. 53, 54), a common hyphomycete, and resting spores of Neozygites parvispora (MacLeod \& Carl) Remaudibere \& S.Keller (FIGS. 55, 56), an obligate entomophthoralean pathogen of thrips, were found in both wheat and ryegrass seed samples. Neozygites parvispora was previously known only from Europe (Keller 1991). Carris and Humber (1998) expanded the known distribution of $N$. parvispora to include New Zealand, and Arizona, Oregon and Tennessee in the USA based on the results of the survey.

Both T. walkeri and N. parvispora are examples of fungi which have become relatively widespread in North America but were not reported until the national KB survey was initiated. The spores of both species are cryptic in ryegrass seed, and can only be detected in seed washes or by soaking the seed overnight in water to render the palea and lemma transparent. The low level of infection of $T$. walkeri in ryegrass may also account for its delayed discovery.

The known geographic distribution of $T$. walkeri includes the southeastern USA, the Willamette Valley in Oregon, and the Kangaroo Valley in Australia. The actual distribution of this species is probably greater, as indicated by the DAR specimen purportedly from New Zealand. In the two regions in the USA where T. walkeri is known to occur, infected L. multiflorum is growing in or around wheat fields, although no infection has been detected in wheat in either the Southeast or Oregon after extensive searches. The Kangaroo Valley is a coastal valley approximately 100 $\mathrm{km}$ southwest of Sydney in New South Wales, Australia. The Kangaroo Valley is separated from the inland wheat-producing areas of New South Wales by hills and forests, but it is a major producer of ryegrass seed which is distributed to other areas of Australia. The ryegrass smut has not been reported outside the Kangaroo Valley (Gordon Murray pers comm), nor are there any known reports of Karnal bunt in wheat in Australia.

The generic placement of T. indica, T. horrida and several other species of Tilletia characterized by large numbers of nonfusing primary sporidia has been controversial. The question of Neovossia Kborn. versus Tilletia has not been adequately resolved. According to Tullis and Johnson (1952), the distinguishing characters of Neovossia include the formation of two types of secondary sporidia, numerous primary spo- 


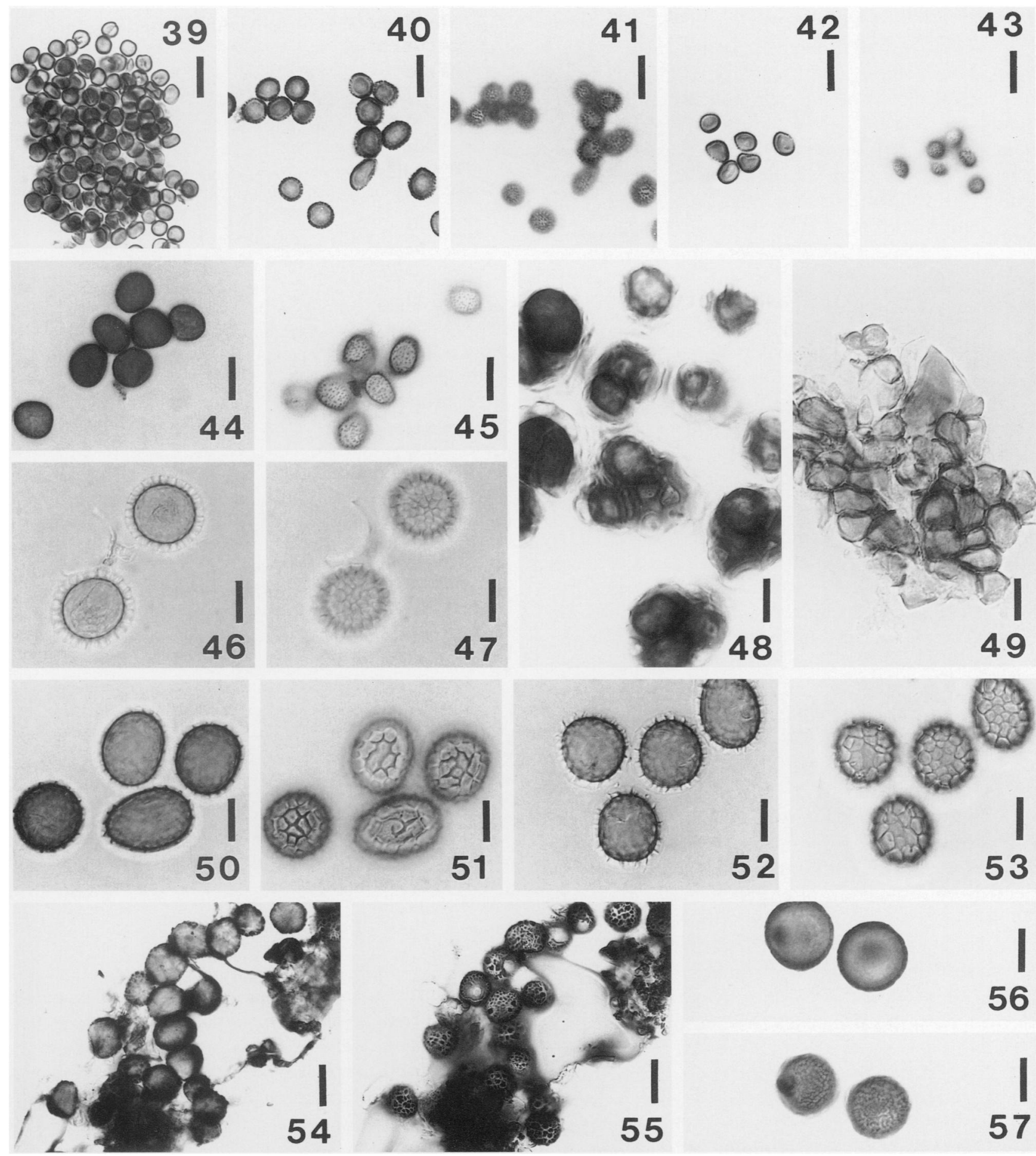

FIGs. 39-57. Lolium fungi (BF). 39. Ustilago hypodytes. 40, 41. Ustilago bullata. 42, 43. Ustilago lolii. 44, 45. Ustilago striiformis. 46, 47. Tilletia lolii. 48. Urocystis bolivari. 49. Entyloma dactylidis. 50, 51. Tilletia tritici. 52, 53. Tilletia controversa. 54, 55. Epicoccum purpurascens. 56, 57. Neozygites parvispora. Scale bars: $39-53=12 \mu \mathrm{m}$.; $54,55=17 \mu \mathrm{m} ; 56,57=12 \mu \mathrm{m}$.

ridia $(20-60+)$ that do not fuse, the presence of a hyaline sheath around the teliospores, and the remnants of the sporogenous hyphae that remain as a conspicuous appendage on the mature teliospores. A gelatinous sheath is frequently present on mature te- liospores of Tilletia spp., but the sporogenous hyphae are not evident as an appendage. As described by these authors, Tilletia species produce only one type of secondary sporidium, fewer primary sporidia (usually 12), and the primary sporidia fuse. Goates and 
Hoffman $(1979,1986)$ noted that the formation of two types of secondary sporidia is typical in Tilletia spp. Goates (1996) and Ingold (1987) clearly illustrate the formation of both allantoid and filiform secondary sporidia in T. tritici, the type species of Tilletia. Tullis and Johnson's (1952) assertion of only one type of secondary sporidium in Tilletia is erroneous, but unfortunately has been used by other authors (Singh and Pavgi 1972, Whitney 1989) to support the placement of $T$. horrida and T. indica in Neovossia.

Differences in number and fusion of primary sporidia were also used by various authors to support the placement of T. horrida and T. indica in Neovossia (Joshi et al 1983, Khanna and Payak 1968, Krishna and Singh 1982b, Singh and Pavgi 1972, Singh et al 1979, Whitney 1989). However, Vbanky (1994) used a somewhat different set of characters to distinguish species of Tilletia and Neovossia. In addition to the large number of primary sporidia that germinate without conjugation, Vbanky considered localized infection, conspicuous appendages on the teliospores, absence of sterile cells, and absence of trimethylamine smell as important characteristics of Neovossia (type $=$ N. moliniae on Molinia caerulea (L.) Moench, also known from Phragmites australis (Cav.) Trin. ex Steudel in Europe, Asia, and N. America). The last two characters are particularly relevant to this discussion, because T. indica, T. horrida and T. walkeri produce sterile cells between the teliospores (Durban and Fischer 1961), and T. indica has a strong trimethylamine odor (Fuentes-Davila 1996, Mitra 1935). No trimethylamine odor has been detected in T. horrida or T. walkeri. Durban and Fischer (1961) rejected the disposition of either $T$. indica or $T$. horrida in Neovossia, noting that the presence of "occasional, fragmentary appendages on immature spores was not sufficiently diagnostic" of Neovossia, and that several other Tilletia species also produce short apiculi on teliospores. Durban (1987) also showed that 15 Mexican species of Tilletia produced primary sporidia that did not fuse on artificial agar, and noted several species other than $T$. indica that produce large numbers of primary sporidia. The only character used to support the placement of T. barclayana, T. horrida and T. indica in Neovossia that has not been adequately demonstrated in other Tilletia species is floret infection. Vbanky (1994) considered systemic infection a characteristic of the genus Tilletia. $\mathrm{He}$ also noted the need for a critical revision of the genus Neovossia. In consideration of the questions surrounding the distinction between the two genera, we concur with Durban (1987) and recommend the use of Tilletia for T. barclayana, T. horrida, T. indica and $T$. walkeri until a more thorough investigation nomically significant differences between the two genera.

\section{KEY TO SMUTS KNOWN TO NATURALLY OCCUR ON LOLIUM SPP.}

1. Spores single $\ldots \ldots \ldots \ldots \ldots \ldots \ldots \ldots \ldots \ldots 2$

1. Spores in balls or densely packed in groups .... 9 2. Spore diam typically less than $15 \mu \mathrm{m} \ldots \ldots \ldots 3$

2. Spore diam typically greater than $15 \mu \mathrm{m} \ldots \ldots 6$

3. Spores apparently smooth, typically $<7 \mu \mathrm{m} \ldots$.

$\ldots \ldots \ldots \ldots \ldots \ldots \ldots \ldots \ldots$ Ustilago hypodytes

3. Spores ornamented ................ 4

4. Spores sparsely ornamented . . . . . . . . 5

4. Spores densely ornamented, typically $>7 \mu \mathrm{m} \ldots$ ....................... bullata

5. Spores typically $5-9 \ldots \ldots \ldots \ldots \ldots \ldots$. lolii

5. Spores typically $8-15 \mu \mathrm{m} \ldots \ldots \ldots$. . striiformis

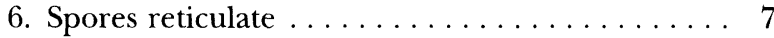

6. Spores tuberculate to subcerebriform ...... $\ldots \ldots \ldots \ldots \ldots$ Tilletia walkeri sp. nov.

7. Spore walls shallowly reticulate (typically $<1.5 \mu \mathrm{m}$ )

$\ldots \ldots \ldots \ldots \ldots \ldots \ldots \ldots \ldots$ T. tritici

7. Spore walls deeply reticulate (typically $>1.5 \mu \mathrm{m}$ ) . 8

8. Spores with inconspicuous sheath, yellowish to pale yellowish-brown.. . . . . . . . . . T. lolii

8. Spores with gelatinous sheath, yellowish to reddish-brown $\ldots \ldots \ldots \ldots \ldots \ldots$. controversa

9. Spores surrounded by sterile cells ... Urocystis bolivari

9. Spores typically densely packed in groups ......

$\ldots \ldots \ldots \ldots \ldots \ldots \ldots$ Entyloma dactylidis

\section{ACKNOWLEDGMENTS}

The authors thank J. Plaskowitz for assistance in preparing the figures, C. Feuillet for correcting the Latin diagnosis, P. M. Gray for technical assistance, and M. Palm, A. Rossman, N. O'Neill, and J. D. Rogers for critically reviewing the manuscript. Bunted seed samples were generously provided by B. Goates, F. Lee, R. Meyer, and G. Peterson. We thank G. Murray, M. Priest, and J. Walker for information on Australian ryegrass and loan of specimens. Funding support by USDA-APHIS to LMC and to the Systematic Botany and Mycology Laboratory is gratefully acknowledged. LMC also gives special thanks to B. Goates for his insightful comments on smuts.

\section{LITERATURE CITED}

Bonde MR, Peterson GL, Schaad NW, Smilanick JL. 1997. Karnal bunt of wheat. Pl Dis 81:1370-1377.

Carris LM, Humber RA. 1998. Neozygites parvispora, an entomophthoralean pathogen of Limothrips sp. associated with Lolium multiflorum in Oregon. Mycologia 90:565568.

Durban R. 1972. Aspects of teliospore germination in North American smut fungi. II. Can J Bot 50:2569-2573.

. 1980. Tilletia aegopogonis, a homo-heterothallic fungus. Phytopathology 70:528-533. 
1987. Ustilaginales of Mexico. Pullman, Washington: Washington State University. $331 \mathrm{p}$.

- Fischer GW. 1961. The genus Tilletia. Pullman, Washington: Washington State University. 138 p.

Farr DA, Bills GF, Chamuris GP, Rossman AY. 1989. Fungi on plants and plant products in the United States. St. Paul: American Phytopathological Society. 1252 p.

Fuentes-Davila G. 1996. Karnal bunt. In: Wilcoxson RD, Saari EE, eds. Bunt and smut diseases of wheat. Concepts and methods of disease management. Mexico, DR: CIMMYT. Chapt 3.

Goates BJ. 1996. Common and dwarf bunt. In: Wilcoxson $\mathrm{RD}$, Saari EE, eds. Bunt and smut diseases of wheat. Concepts and methods of disease management. Mexico, DR: CIMMYT. Chapt 2.

, Hoffman JA. 1979. Somatic nuclear division in Tilletia species pathogenic on wheat. Phytopathology 69: 592-598.

-1986 . Formation and discharge of secondary sporidia of the bunt fungus, Tilletia foetida. Mycologia 78:371-379.

Holton CS. 1949. Observations on Neovossia indica. Indian Phytopathol 2:1-5.

Ingold CT. 1987. Germination of teliospores in certain smuts. Trans Brit Mycol Soc 88:355-363.

Joshi LM, Singh DV, Srivastava KD, Wilcoxson RD. 1983. Karnal bunt: a minor disease that is now a threat to wheat. Bot Rev 49:309-330.

Keller S. 1991. Arthropod-pathogenic Entomophthorales of Switzerland. II. Erynia, Eryniopsis, Neozygites, Zoophtho$r a$ and Tarichum. Sydowia 43:39-122.

Khanna A, Payak MM. 1968. Teliospore morphology of some smut fungi. II. Light microscopy. Mycologia 60: $655-662$.

Krishna A, Singh RA. 1982a. Effect of physical factors and chemicals on the teliospore germination of Neovossia indica. Indian Phytopathol 35:448-455.

- 1 1982b. Taxonomy of Karnal bunt fungus: evidence in support of genus Neovossia. Indian Phytopathol 35:544-545.
Lindeberg B. 1959. Ustilaginales of Sweden. Symb Bot Upsal 16:1-175.

Matsumoto T, Bell T. 1989. Laboratory guide to smut fungi. Sacramento: California Dept. of Food and Agriculture. $390 \mathrm{p}$.

Mitra M. 1935. Stinking smut (bunt) of wheat with special reference to Tilletia indica. Indian J Agric Sci 5:1-24.

Peterson GL, Bonde MR, Dowler WM, Royer MH. 1984 Morphological comparisons of Tilletia indica Mitra from India and Mexico. Phytopathology 74:757 (abstr).

Pimentel G, Carris LM, Levy L, Meyer RJ. 1998. Genetic variability among isolates of Tilletia barclayana, $T$. indica and allied species based on RAPD and PCRRFLP analysis. Mycologia 90:1017-1027.

Royer MH, Rytter J. 1988. Comparison of host ranges of Tilletia indica and T. barclayana. Pl Dis 72:133-136.

Singh RA, Pavgi MS. 1972. Cytology of teliospore germination and development of Neovossia horrida. Riso 21: 259-268.

- Whitehead MD, Pavgi MS. 1979. Taxonomy of Neovossia horrida (Ustilaginales). Sydowia 32:305-308.

Smilanick JL, Hoffman JA, Royer MH. 1985. Effect of temperature, $\mathrm{pH}$, light and desiccation on teliospore germination of Tilletia indica. Phytopathology 75:14281431.

Smith OP, Peterson GL, Beck RJ, Schaad NW, Bonde MR. 1996. Development of a PCR-based method for identification of Tilletia indica, causal agent of Karnal bunt of wheat. Phytopathology 86:115-122.

Tullis EC, Johnson AG. 1952. Synonymy of Tilletia horrida and Neovossia barclayana. Mycologia 44:773-788.

Vbanky K. 1994. European smut fungi. New York: Gustav Fischer. 570 p.

Whitney NG. 1989. Taxonomy of the fungus causing kernel smut of rice. Mycologia 81:468-471.

Ykema RE, Floyd JP, Palm ME, Peterson GL. 1996. First report of Karnal bunt of wheat in the United States. Pl Dis 80:1207.

Zundel GL. 1953. Ustilaginales of the world. State College, Pennsylvania: Pennsylvania State College. 410 p. 